\title{
The nature and fate of natural resins in the geosphere-III.* Re-evaluation of the structure and composition of Highgate Copalite and Glessite
}

\author{
Ken B. ANDersont and R. E. Botto \\ Chemistry Division, Argonne National Laboratory, 9700 S. Cass Avenue, Argonne, IL 60439, U S.A.
}

(Received 8 July 1992; accepled in revised form 29 December 1992)

\begin{abstract}
The results of GC-MS, Py-GC-MS and spectroscopic (solid state ${ }^{13} \mathrm{C}$ NMR) studies of the structure and composition of two resinites, viz. Highgate Copalite and Glessite, which have been previously described as "fossil elemu" are described. GC-MS analyses of Highgate Copalite establısh that this resinite is composed of a simple mixture of diterpenoid resin acids and $n$-alkyl materials. Based on comparison of these data with similar data obtained by analysis of modern rosin, it is concluded that this resinite is most probably derived from the resin of an undetermined species of pine In order to accommodate resinites of this general character, it is proposed that an additional class, viz Class $\mathrm{V}$, be added to the classification system for resinites which we have prevıously proposed (Anderson et al., 1992). Py -GC-MS analysis of Glessite establish that this material is a typical Class la resinite closely related to Succinite ("normal" or "typical" Baltic Amber). It is concluded that the previously assigned structural character of these two resinites is open to question
\end{abstract}

Key words--resinite, Succinite, Glessite, Highgate Copalte, classıficatıon, GC-MS, Py-GC-MS

\section{INTRODUCTION}

Fossil organic products derived from the resins of higher plants are both widespread and abundant in the geosphere. These materials are generally referred to by their common name, amber, but for scientific purposes are more correctly described by their geologic or petrographic name as resınites. In a recent publication (Anderson et al., 1992), we have suggested that the majority of resinites fall into one of a small number of discrete classes, and have described a classification system, based on structural characteristics, for the differentiation and nomenclature of these materials. As part of efforts undertaken to establish this classification system, we have characterized a significant number of resinite samples obtained from sediments of various kinds and ages, from all over the globe. A number of resinites which had previously been described as "fossil elemi" (Frondel, 1967a, b) were deliberately included in these analyses, since these resinites were considered to represent a distinct and unique form of fossil resin. Hence, elucidation and confirmation of details of their organic molecular structures was considered to be an important research objective.

Elemi are resins derived from various plants of the Burseraceae (especially Protium, Canarium, and

*For Part II of series, see Anderson et al. (1992) Org Geochem. 18, 829-841.

tTo whom all correspondence should be addressed at Amoco Oil Company, Mail Station H-9, Bldg. 700, P.O Box 3011, Naperville, IL 60566-7011, U.S.A.
Bursera). These materials are generally rich in $\alpha$ and $\beta$-amyrin and related pentacyclic triterpenoids based on the ursane and oleanane (and euphane) carbon skeletons (Pernet, 1972) (see structures illustrated in Scheme 1). On the basis of X-ray diffraction data, Frondel $(1967 \mathrm{a}, \mathrm{b})$ concluded that a number of resınites, including those with which this report is concerned, contained or were based on structures related to $\alpha$-amyrin, and hence represented fossil analogues of this type of modern resin. For the purposes of the present study, samples of three resınites characterized by Frondel (1967a, b) were obtained from the collection of the Smithsonian Institute, and have been subjected to modern chromatographic and spectroscopic analyses. The results obtained from the analyses of two of these, viz. Highgate Copalite and Glessite, are described herein. Results of analyses of the third sample, Guayaquilte, will be described in a subsequent report.

Highgate Copalite, which was first described in the scientific literature by Thomson (1813) and subsequently by Johnston (1839) (these are the earliest reports of which the authors are aware), is found in Eocene strata, largely clays, in the Highgate Hill area of London (U.K.). Glessite is an often "milky" resinite which co-occurs with succinite in Miocene(?) (so called "blue earth") strata in the eastern baltic and other areas of Europe. Sample reference numbers, elemental compositions and other details of the samples described herein are given in Table 1. 


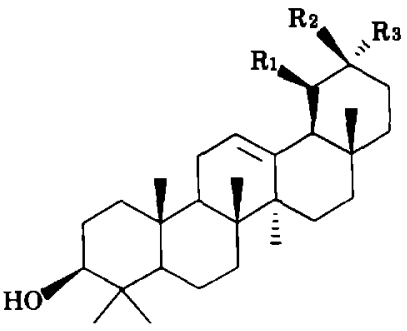

$\alpha$-Amyrin : $\mathbf{R}_{1}=\mathrm{R}_{3}=$ Methyl, $\mathbf{R}_{2}=\mathrm{H}$

B-Amyrin : $\mathrm{R}_{1}=\mathrm{H}_{1} \mathbf{R}_{2}=\mathrm{R}_{\mathbf{3}}=$ Methyl

Scheme 1. Structures of $\alpha$ and $\beta$ Amyrin

EXPERIMENTAL

Cross Polarization/Magic Angle Spinning (CP/MAS) ${ }^{13} \mathrm{C}$ NMR spectra were recorded on a Bruker CXP-100 NMR spectrometer, operating at a field of $2.3 \mathrm{~T}\left(25.18 \mathrm{MHz}\right.$ for $\left.{ }^{13} \mathrm{C}\right)$ with quadrature phase detection. Approximately $250 \mathrm{mg}$ of sample was packed into a $300 \mu$ l ceramic sample rotor which was spun at about $4 \mathrm{kHz}$. Additional details of operating conditions are described in detail elsewhere (Anderson et al., 1992).

Py-GC-MS analyses were conducted on an HP 5890(II) GC directly coupled to an HP 5970 mass selective detector. Pyrolyses were carried out using a CDS "Pyroprobe" pyrolysis system. Pyrolytic methylations were achieved by co-pyrolysis with tetramethyl ammonium hydroxide. Further details of the experimental procedures used in Py-GC-MS analyses, and the basis for using these conditions, have been reported elsewhere (Anderson and Winans, 1991). GC-MS analyses were carried out using the same equipment used for Py-GC-MS analyses, except that sample introduction by on-column injection was employed for these analyses.

Chromatographic conditions used to obtain the data reported herein are as follows: (i) Highgate Copalite and modern Rosin-Column $=60 \mathrm{~m}$
DB-1701, Temperature program $=T_{\text {(nntal) }}=80^{\circ} \mathrm{C}$ (1.5 min), Ramp rate $=4^{\circ} \mathrm{C} / \mathrm{min} T_{\text {(6nal) }}=280^{\circ} \mathrm{C}$. (ii) Glessite and Succinite - Column $=60 \mathrm{~m} \mathrm{DB}-1701$, $T_{\mathrm{Py}}=480^{\circ} \mathrm{C}$. Temperature program: $T_{\text {(intal) }}=40^{\circ} \mathrm{C}$ (1.5 min), Ramp rate $=4^{\circ} \mathrm{C} / \mathrm{min}, T_{\text {(final) }}=280^{\circ} \mathrm{C}$. (iii) Glessite and Succinite ("optimized" for additional resolution of diterpenoid components. Data illustrated in Fig. 4.) - Column $=30 \mathrm{~m} \mathrm{DB-5}$, Temperature program: $T_{\text {(inual) }}=50^{\circ} \mathrm{C}(2.0 \mathrm{~min})$, Ramp rate (1) $=20^{\circ} \mathrm{C} / \mathrm{min}, \quad T(1)=180^{\circ} \mathrm{C}$, Ramp rate $(2)=$ $1.5^{\circ} \mathrm{C} / \mathrm{min}, T(2)=230$, Ramp rate $(3)=8^{\circ} \mathrm{C} / \mathrm{min}$, $T_{\text {(inal) }}=310^{\circ} \mathrm{C}(12.5 \mathrm{~min}), \quad T_{\mathrm{Py}}=300^{\circ} \mathrm{C}$ (Additional data, not illustrated, obtained by pyrolysis using $T_{\mathrm{Py}_{\mathrm{y}}}=480^{\circ} \mathrm{C}$.)

\section{RESULTS AND DISCUSSION}

Spectroscopic analyses of both Highgate Copalite and Glessite, using solid state ${ }^{13} \mathrm{C}$ NMR, (illustrated in Fig. 1) and FTIR described elsewhere (Beck, 1986; Kosmowska-Ceranowicz and Krumbiegel, 1990) indicate significant differences between the organic structures of these resinites. Furthermore, comparison of these data with data from modern elemi resin (see Fig. 1) strongly contradicts the earlier conclusion (Frondel, 1967a, b), that these resinites are based on, derived from, or are comparable to, modern elemi. These data do, however, suggest structural similarity between each of these resinites and other resins and resinites. Therefore, based on leads suggested by spectroscopic data, comparative studies of (i) Highgate Copalite and modern (Pinus) rosin, and (ii) Glessite and Baltic Amber (Succinite) have been undertaken. Since analyses of these resinites were undertaken independentiy, it is appropriate to separately discuss the resulting data.

\section{HIGHGATE COPALITE}

Solid state ${ }^{13} \mathrm{C}$ NMR analyses of Highgate Copalite, illustrated in Fig. 1, strongly suggest that this resinite is closely comparable to modern rosin, which

Table 1 Sample origins, reference numbers and elemental compositions of resinites and resins described in this report

\begin{tabular}{llccccc}
\hline Sample & \multicolumn{1}{c}{ Origin } & C & H & N & O & S \\
\hline $\begin{array}{l}\text { Highgate Copalite } \\
\text { USNM R 7316 }\end{array}$ & $\begin{array}{l}\text { Highgate Hill, } \\
\text { London }\end{array}$ & 69.5 & 8.4 & - & $221^{*}$ & ND \\
$\begin{array}{l}\text { Modern Rosin } \\
\text { (Pinus) }\end{array}$ & $\begin{array}{l}\text { Sigma Chemical } \\
\text { Co. }\end{array}$ & 732 & 90 & - & $178^{*}$ & - \\
$\begin{array}{l}\text { Glessute } \\
\text { USNM R 7294 }\end{array}$ & "Prussia" & 781 & 97 & - & $122^{*}$ & ND \\
$\begin{array}{l}\text { Succinute } \\
\text { USNM 353431 }\end{array}$ & Baltic Region & 79.5 & 10.1 & - & $10.11^{\dagger}$ & - \\
$\begin{array}{l}\text { Modern Elemi } \\
\text { (Burseraceae) }\end{array}$ & $\begin{array}{l}\text { Sigma Chemical } \\
\text { Co. }\end{array}$ & 803 & 110 & - & $8.7^{*}$ & - \\
\hline
\end{tabular}

"Oxygen determined by difference.

†Direct oxygen determination.

-Below analytical detection limit

$\mathrm{ND}=$ not determined. 

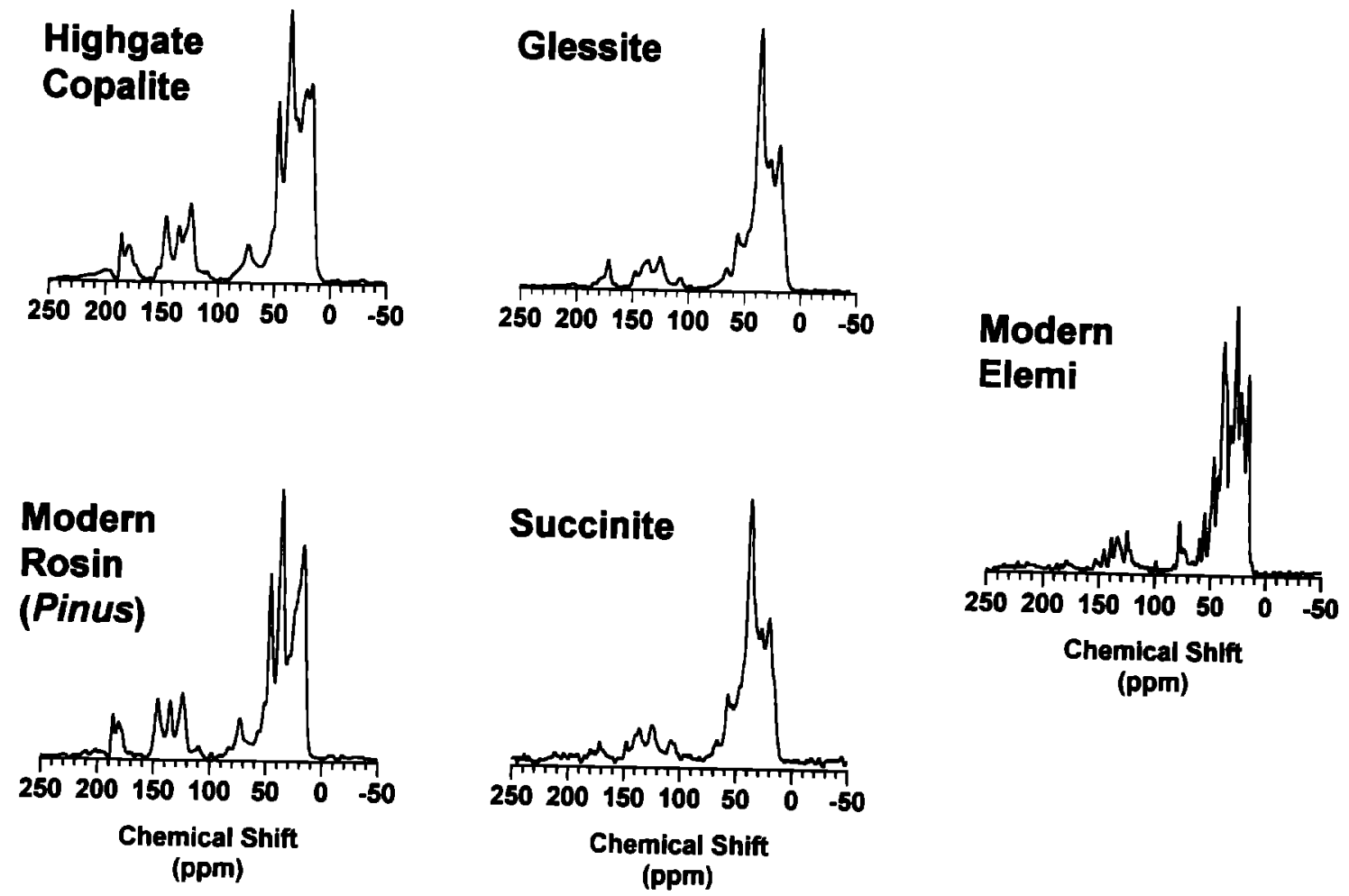

Fig. 1. CP/MAS solid state ${ }^{13} \mathrm{C}$ NMR spectra of resins and resinites described in this report. (See also, Lambert et al., 1988).

is produced commercially from the resins of various species of pine. The ${ }^{13} \mathrm{C}$ NMR spectra of both Highgate Copalite and rosin (Fig. 1) show similar patterns in the aliphatic region (10-50 ppm). Both spectra also exhibit resonances characteristic of secondary alcohols at $\sim 72 \mathrm{ppm}$, and evidence for small amounts of tertiary alcohols at $\sim 83 \mathrm{ppm}$. The pattern of resonances due to carbon-carbon double bonds (110-150 ppm) are also similar in both samples, although the Highgate Copalite sample shows slightly enhanced intensity at $\sim 127 \mathrm{ppm}$, indicating slightly greater amounts of endocyclic olefin and/or protonated aromatic structures. Carboxylic acids are also clearly apparent in both samples (resonances at 175-187 ppm) as are small quantities of carbonyl groups (190-210 ppm).

Modern pine resins (and rosins) are known to be based primarily on diterpenoid "resin acids", particularly acids based on the abietane, pimarane and iso-pimarane carbon skeletons (Soltes and Zinkel, 1989). Resins of this type are conveniently analyzed as their corresponding methyl esters by gas chromatography, especially in combination with mass spectrometry (GC-MS). Preliminary analyses established that Highgate Copalite, like modem pine resins (and rosin), is completely soluble in both diethylether and methylene chloride. (This is not true of Glessite-see discussion later.) Hence, in order to determine the extent of the similarity between Highgate Copalite and modern rosin, which is suggested by the spectro- scopic analyses, parallel GC-MS analyses of these two materials were undertaken.

Total ion chromatograms obtained from these analyses are illustrated in Fig. 2. It is immediately apparent from the data illustrated in Fig. 2 that the distributions of diterpenoids in these samples are strikingly similar. Twelve distinct diterpenes (viz. compounds A-L) and seven $n$-alkyl compounds have been identified in Highgate Copalite from these data. Nine of the 12 diterpenoids identified in Highgate Copalite, including all of the major components, are also observed in the rosin sample. All of the nine diterpenoid components observed in the rosin sample are also observed in Highgate Copalite. Furthermore, compounds A, B and I, which are not observed in the modern rosin, are degradation products of other diterpenoids, and hence may reflect the maturity of the Highgate Copalite sample, rather than fundamental differences in the primary compositions of the samples (compounds $\mathrm{A}$ and $\mathrm{B}$ may also be primary natural products in their own right-see Zinkel et al., 1969). This suggests that these materials are likely to have similar botanical origins, and hence, that Highgate Copalite is likely to be derived from the resin of an undetermined species of pine.

The observation of $n$-alkanoic acids and $n$-alkanes in the Highgate Copalite sample is also consistent with this conclusion, despite the fact that these are not observed in the rosin sample. These are normal constituents of many pine resins (see for example, 

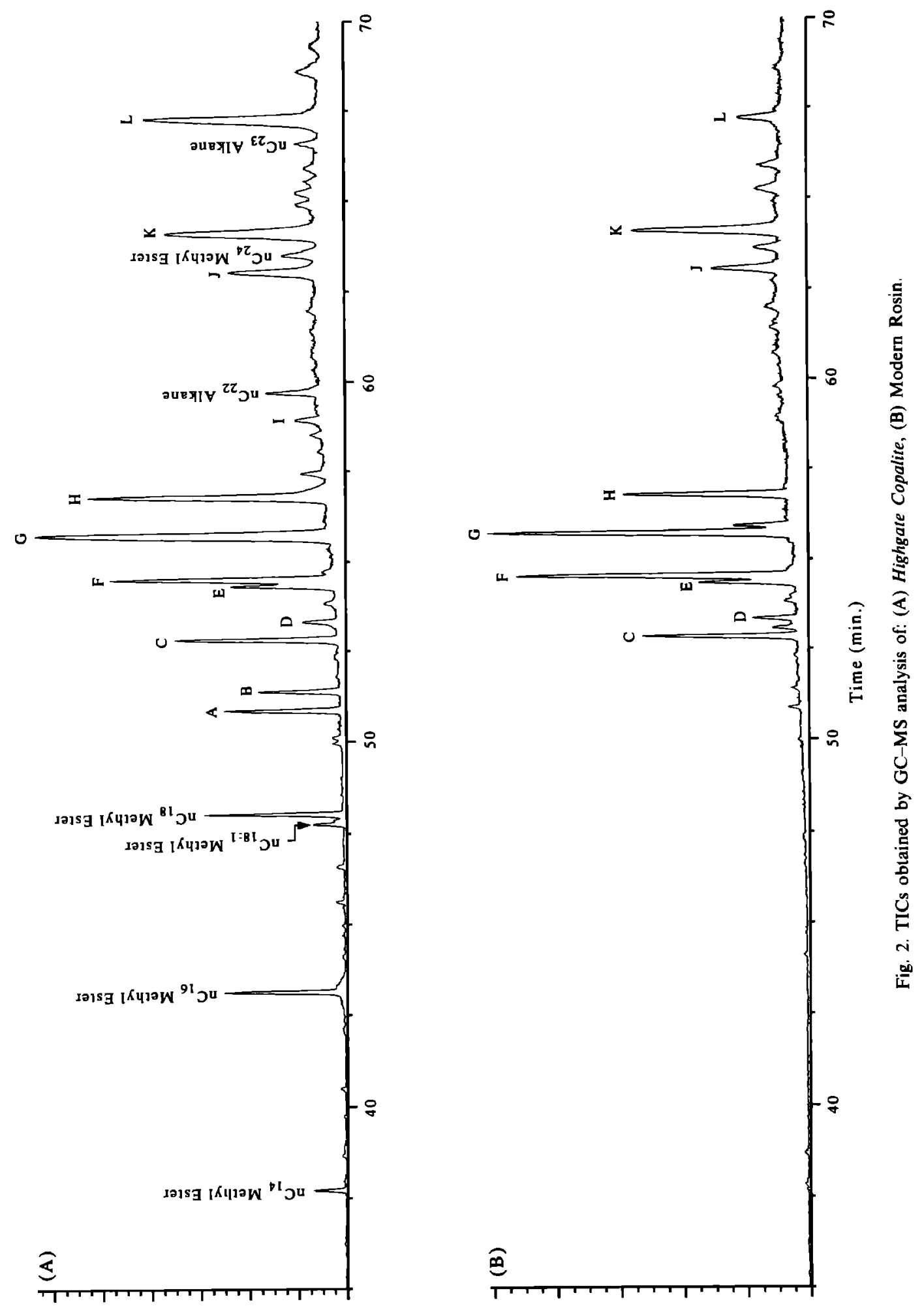
Table 2. MS data and corresponding structural assignments for methyl esters of components Highgate Copalite and modern Pinus Rosin

\begin{tabular}{|c|c|}
\hline Compound & MS data and assignments \\
\hline$\overline{\mathrm{A}}$ & 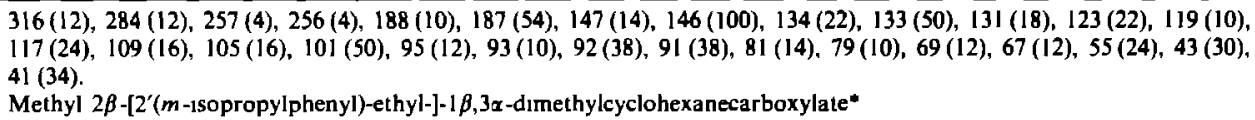 \\
\hline B & $\begin{array}{l}316(10), 284(36), 269(4), 256(6), 192(18), 187(12), 147(16), 146(100), 134(10), 133(44), 131(22), 123(14), 117(24), \\
111(10), 109(22), 105(14), 101(12), 95(18), 92 \text { (18), } 91(30), 81(12), 69(12), 67(12), 59(10), 55(22), 43(18), 41(30) . \\
\text { Methyl } 2 \beta-\left[2^{\prime}(m \text {-isopropylphenyl)-ethyl]-1 } 1 \beta, 3 \beta \text {-dimethylcyclohexanecarboxylate* }\right.\end{array}$ \\
\hline C & $\begin{array}{l}316(14), 301(12), 257(14), 241(8), 181(8), 180(16), 133(14), 122(12), 121(100), 107(10), 105(16), 91(22), 79(20), \\
67(12), 55(16), 41(18) \\
\text { Methyl pimarate† }\end{array}$ \\
\hline D & $\begin{array}{l}316(24), 301(28), 257(20), 241(16), 181(16), 180(10), 133(16), 121(100), 109(10), 107(22), 105(26), 93(24), 91(20), \\
81(12), 79(20), 55(20), 41(24) \\
\text { Methyl sandaracopimarate }\end{array}$ \\
\hline $\mathbf{E}$ & $\begin{array}{l}316(66), 301(100), 257(8), 241(68), 213(16), 185(20), 159(14), 149(22), 148(22), 133(14), 117(12), 107(14), 106(16) \text {, } \\
105(18), 93(12), 91(18), 79(8), 77(10), 55(10), 43(22), 41(24) \text {. } \\
\text { Methyl palustrate† }\end{array}$ \\
\hline $\mathbf{F}$ & $\begin{array}{l}316(30), 301(14), 287(16), 257(48), 256(48), 241(100), 227(14), 201(20), 187(30), 173(14), 145(14), 133(22), 131(18), \\
121(36), 119(38), 109(24), 107(24), 105(46), 91(50), 81(32), 79(48), 67(28), 55(48), 41(58) . \\
\text { Methyl isopimarate† }\end{array}$ \\
\hline G & $\begin{array}{l}314(14), 299(16), 240(20), 239(100), 197(6), 173(6), 141(8), 43(14), 41(10) . \\
\text { Methyl dehydroabietate† }\end{array}$ \\
\hline H & $\begin{array}{l}316(80), 301(8), 273(14), 257(32), 256(100), 241(64), 213(38), 185(28), 136(22), 131(30), 121(50), 105(40), 93(24), \\
91(40), 79(24), 67(18), 55(28), 43(34), 41(42) \text {. } \\
\text { Methyl abietate† }\end{array}$ \\
\hline $\mathbf{I}$ & $\begin{array}{l}312(26), 297(14), 238(20), 237(100), 181(10), 171(6), 155(8), 141(10), 109(22), 41(8) \text {. } \\
\text { Methyl } 8,11,13,15 \text {-abietatetraenoatef }\end{array}$ \\
\hline $\mathrm{J}$ & $\begin{array}{l}330(14), 312(28), 253(6), 238(20), 237(100), 195(22), 162(14), 141(8), 91(6), 43(12), 41(14) \\
\text { Methyl 3-hydroxydehydroabietate }\end{array}$ \\
\hline $\mathbf{K}$ & $\begin{array}{l}330(22), 316(22), 315(100), 255(80), 237(30), 197(12), 162(10), 59(22), 43(58) . \\
\text { Methyl 15-hydroxydehydroabietatef }\end{array}$ \\
\hline $\mathrm{L}$ & $\begin{array}{l}328(50), 313(4), 296(12), 269(10), 268(10), 254(20), 253(100), 213(12), 211(10), 187(16), 141(6), 128(8), 115(8), \\
91(6), 43(12), 41(12) \\
\text { Methyl 7-keto-dehydroabietate† }\end{array}$ \\
\hline
\end{tabular}

- Structure assigned on the basis of comparison of experimental MS data with literature data. Note that there is some confusion in the literature concerning the assignment of these compounds. MS data reported by Takeda et al (1968) and Zinkel et al. (1969) closely match the experimental data for compounds $A$ and B. However, the structures assigned by these authors have subsequently been revised (Herz and Mohanraj, 1980) The assignments for compounds A and B given above and illustrated in Scheme I correctly reflect the reassigned structures of the compounds for which Takeda et al. (1968) and Zinkel et al (1969) have reported MS data (Herz, 1992, personal communication). See discussion in the hterature concerning the structure and stereochemistry of these two compounds (Takeda $e t$ al, 1968, 1969; Zinkel et al, 1969; Herz and Mohanraj, 1980; Soltes and Zinkel, 1989)

+Structure confirmed by companson and co-elution with authentic standard.

tStructure assigned on the basis of companson of expenmental data with data from authentic standards. (Zınkel, 1991, personal communication).

Other assignments are based on interpretation of expenmental MS data

Zinkel and Foster, 1980; Hafizoğlu, 1983) but are removed during commercial refining for rosin production. Mass spectral data and assignments for compounds A-L are given in Table 2, MS data for $n$-alkyl components are not reproduced, but closely correspond to literature data for these compounds. Structures for compounds $\mathrm{A}-\mathrm{L}$ are illustrated in Scheme 2.

It must be noted at this point that the structure and composition of this resinite place it outside the range of resinite structures presently described under the classification system which we have recently proposed (Anderson et al., 1992). Beck and Shennan (1991) have reported that the infrared absorption spectrum of Settlingite, a resinite which is obtained from the locale around Settling Stones (Northumberland, U.K.) [and which was also reported by Frondel to give a sharp X-ray diffraction pattern (Frondel, 1967b)] is "virtually identical with [that] of crude abietic acid". These authors conclude that this resinite (Settlingite) is "an essentially unchanged coniferous resin, most likely of the sub-genus Diploxylon of the genus Pinus". Based on this observation, and on the observations described above for Highgate Copalite, it is apparent that these resinites represent a structurally distinct form of resinite, which satisfies the criteria [described in our previous report (Anderson et al., 1992)] that only distinct forms of resinite which are known from more than one site be included in the classification system which we have proposed therein. Therefore, we propose that an additional class of resinite, Class $V$, be added to the classification system, viz.

\section{CLASS V}

Basic structural character is non-polymeric diterpenoid carboxylic acid, (especially based on the abietane, pimarane and iso-pimarane carbon skeletons). 
<smiles>CO[C@H]1[C@@H](Cc2cccc(C(C)C)c2)CCC[C@]1(C)OC</smiles>

A<smiles>CO[C@H]1CCC2=C(CCC(C(C)C)=C2)[C@@]2(C)CCC[C@]1(C)O2</smiles>

E (37)<smiles>C=C(C)c1ccc2c(c1)CCC1[C@@](C)(OC)CCC[C@@]21C</smiles>

I<smiles>CO[C@H]1CCCC(C)(C)[C@@H]1Cc1cccc(C(C)C)c1</smiles>

B<smiles>C=C[C@]1(C)CCC2C(=CCC3C2CCCC3(C)OC)C1</smiles>

F (36)<smiles>CO[C@H]1CCc2cc(C(C)C)ccc2[C@@]1(C)CCC(C)O</smiles>

$\mathrm{J}$<smiles>C=C[C@]1(C)C=C2CC[C@]3(C)[C@@H](OC)CCC[C@]3(C)[C@H]2CC1</smiles>

C<smiles>CCC[C@]1(C)c2ccc(C(C)C)cc2CC[C@@H]1OC</smiles>

G (38)<smiles>CO[C@]1(C)CCCC2(C)c3ccc(C(C)(C)O)cc3CC21</smiles>

$\mathrm{K}$<smiles>C=C[C@]1(C)C=C2CCC3C(CCC[C@@]3(C)OC)C2CC1</smiles>

D (34)<smiles>CO[C@@H]1CCCC2(C)C3CC=C(C(C)C)C=C3C=CC12</smiles>

H (40)<smiles>COC(=O)C1CC(=O)c2cc(C(C)C)ccc2[C@]12CCCC2(C)C</smiles>

L

Scheme 2. Structures of diterpenoids identified in Highgate Copalite. MS data are given in Table 2.

$n$-Alkanoic acids and $n$-alkanes may also be present in minor amounts.

Examples: Highgate Copalite, Settlingite.

Nearest equivalent modern resin: Rosin (and unrefined pinaceous resins).

Most probable botanical affinity: Pinaceae.

\section{GLESSITE}

As shown in Fig. 1, ${ }^{13} \mathrm{C}$ NMR analyses of Glessite suggest a high degree of similarity between this resinite and Succinite ("normal" or "typical" Baltic Amber). (A detailed discussion of the solid state ${ }^{13} \mathrm{C}$ NMR spectra of Succinite and related resinites has been reported elsewhere (Lambert and Frye, 1982; Lambert et al., 1988), and hence these data will not be further discussed here.) This correspondence of structure is also supported by the results of FTIR analysis, (Kosmowska-Ceranowicz and Krumbiegel, 1990). Based on these data, and given that both of these resinites are collected from similar European sediments of generally similar (Miocene) age (Langenheim, 1990), comparative analyses of Glessite and Succinite have been undertaken.

Baltic Amber (Succinite) has been the subject of a number of systematic chemical studies, including analysis of extractable materials by GC-MS (Mills et $a l$, , 1984/85), and considerable detail of the structure and composition of this material is now known.
However, due to the presence of significant amounts of insoluble, high molecular weight material, Succinite is not well suited for analysis by conventional GC-MS techniques. As noted above, preliminary analyses conducted by the authors established that Glessite is also only partially soluble in organic solvents, and hence is also largely unsuited to conventional GC-MS analyses. In a recent publication we have reported that pyrolysis $\mathrm{GC}-\mathrm{MS}$ (Py-GC-MS) using simultaneous pyrolytic methylation of acidic materials is a useful technique for the characterization and classification of resinites, including Succinite (Anderson and Winans, 1991; Anderson et al., 1992). Therefore, in order to determine as completely as possible the extent of structural and compositional similarity between these two materials, parallel Py-GC-MS analyses of both Glessite and Succinite have been undertaken.

Total ion chromatograms obtained by Py-GC-MS analysis of both Glessite and Succinile are illustrated in Fig. 3. Twenty six significant non-diterpenoids (viz. compounds 1-26) observed in the pyrolysates of these samples have been shown by comparison of their mass spectra to be common to both resinites. Furthermore, data illustrated in Fig. 3 also establish that compounds 1-26 occur in generally similar abundances in the pyrolysates of both resinites. This suggests that the precursor structures of these compounds also occur in similar abundances in these two 


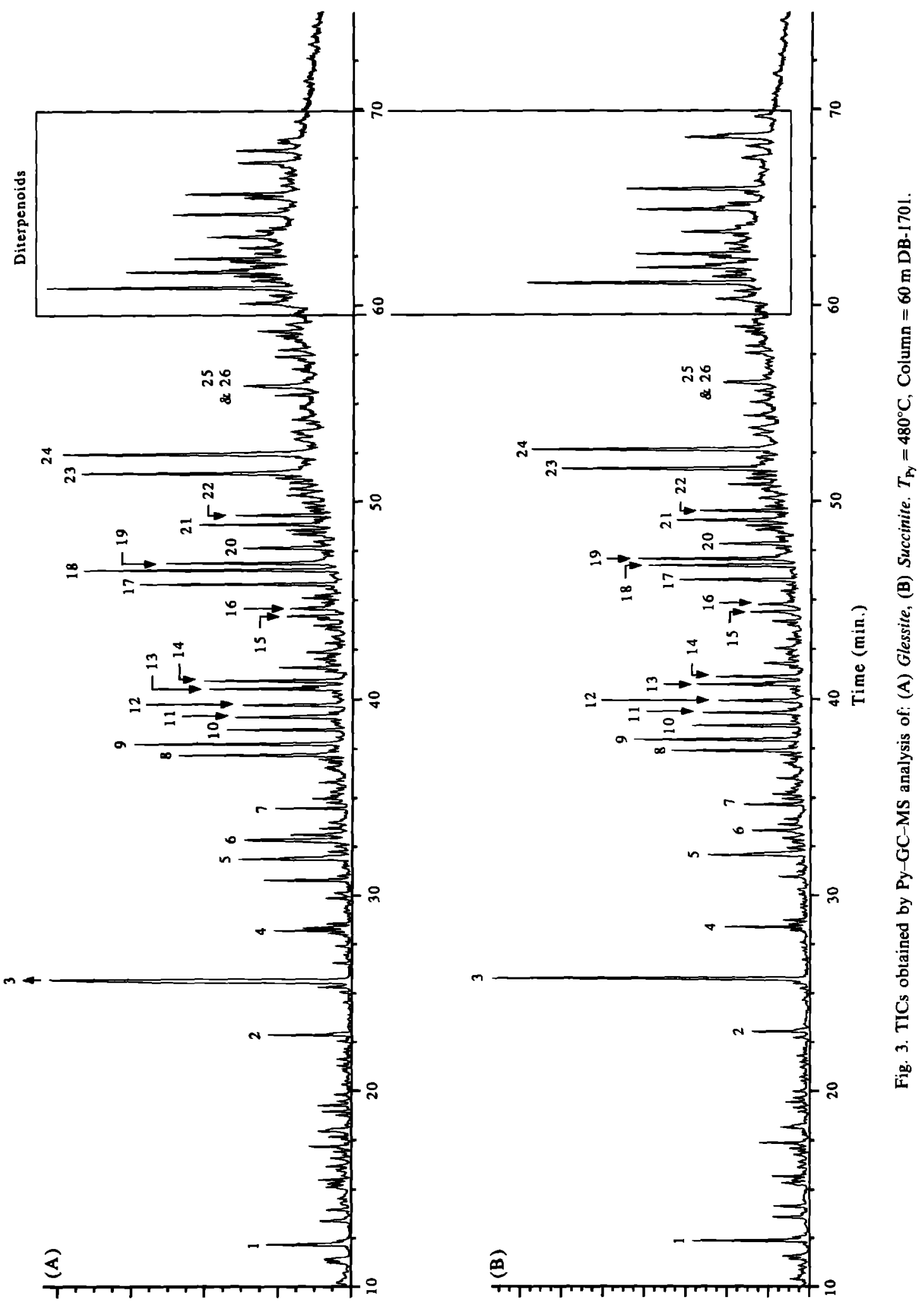


Table 3. MS data from Py-GC-MS analysis of Glessile and Succinire (non diterpenoids)

\begin{tabular}{ll}
\hline Compound & \multicolumn{1}{c}{ MS data and assignments } \\
\hline 1 & $110(22), 95(100), 82(18), 81(12), 79(8), 77(10), 67(66), 55(20), 53(12), 41(26)$. \\
2 & $154(2), 129(2), 109(100), 93(6), 91(6), 81(16), 79(8), 77(8), 67(38), 55(10), 45(12), 41(14)$. \\
3 & $115(100), 114(30), 87(24), 59(68), 55(82), 45(10), 42(8)$. \\
& Dimethyl succinate. \\
5 & $140(2), 109(100), 91(8), 81(18), 79(14), 77(10), 67(48), 55(12), 43(14), 41(18)$. \\
& $178(18), 163(56), 149(16), 135(14), 122(16), 121(20), 109(10), 108(24), 107(68), 93(32), 91(22), 81(100), 79(20)$,
\end{tabular}
$77(14), 67(18), 55(18), 53(16), 41(34)$.

$178(30), 163(62), 149(32), 135(24), 121(48), 107(82), 93(58), 91(36), 81(100), 79(40), 77(32), 67(38), 55(38), 53(32)$, $41(58)$

$192(34), 177(100), 149(26), 136(16), 135(18), 123(38), 122(38), 121(40), 109(30), 107(72), 105(34), 95(70), 93(50)$, $91(62), 81(80), 79(52), 77(38), 69(60), 67(34), 65(22), 55(40), 53(26), 41(94)$.

$190(54), 175(66), 161(22), 147(40), 133(40), 121(38), 119(82), 108(98), 107(40), 105(74), 95(26), 93(100), 91(76)$, $81(32), 79(48), 77(52), 67(22), 55(40), 53(30), 41(92)$.

$192(18), 177(34), 161(8), 149(24), 136(16), 133(14), 121(58), 119(22), 109(16), 107(30), 105(24), 95(100), 93(28)$, $91(32), 83(20), 81(20), 79(24), 77(20), 67(24), 55(34), 41(62)$.

$190(58), 175(70), 161(22), 147(40), 133(48), 121(50), 119(76), 108(76), 105(84), 95(32), 93(100), 91(86), 81(24)$, $79(46), 77(60), 67(20), 65(30), 55(38), 53(26), 41(72)$.

$206(24), 191(72), 163(12), 150(16), 135(44), 121(84), 109(52), 107(38), 95(100), 91(30), 83(28), 81(24), 77(22)$, $69(32), 67(24), 55(46), 43(26), 41(82)$.

$204(62), 189(32), 175(6), 161(48), 148(22), 147(26), 135(44), 133(56), 121(40), 119(74), 108(64), 107(66), 105(80)$, $95(28), 93(62), 91(82), 79(50), 77(48), 69(20), 67(18), 65(28), 55(58), 53(34), 41(100)$.

$222(8), 207(6), 190(16), 177(100), 161(16), 149(10), 147(14), 135(18), 133(20), 121(42), 119(44), 107(60), 105(46)$, $98(54), 95(82), 93(38), 91(42), 81(54), 79(52), 77(30), 67(26), 55(42), 45(58), 41(62)$

Corresponds to compound IXa from Anderson and Winans (1991).

$236(18), 221$ (10), 204 (14), $177(84), 176(54), 161$ (100), 147 (10), $133(12), 121(20), 119(44), 107(42), 105(96), 95(32)$, $93(28), 91$ (30), $81(38), 79(32), 77(24), 67(24), 55(22), 41$ (62).

Naphthalene-1 $(\beta)$-carboxylic acid-1,2,3,4,4a,7,8,8a-octahydro-1,4a( $\beta), 6$-trimethyl, methyl ester. Corresponds to compound $\mathrm{Xa}$ from Anderson and Winnans (1991).

$218(12), 203(24), 189(100), 173(18), 161(20), 159(20), 147(18), 145(20), 133(20), 123(22), 107(64), 105(40), 95(42)$, $91(58), 81(50), 79(62), 77(34), 65(22), 55(28), 45(34), 41(50)$.

$236(20), 221(18), 204(16), 191(58), 189(56), 161(26), 149(40), 147(28), 135(72), 133(28), 121(68), 119(70), 107(50)$ $105(44), 98(28), 95(100), 93(52), 91(58), 83(30), 81(44), 79(50), 77(46), 67(32), 55(62), 45(68), 43(30), 41(86)$.

$234(24), 219(4), 202(14), 189(18), 187(58), 173(22), 159(40), 146(30), 145(50), 133(76), 132(100), 119(90), 107(30)$, $105(46), 91(70), 79(34), 77(30), 67(20), 65(16), 55(50), 45(64), 41(68)$. $105(32), 91(48), 79(26), 77(20), 67(16), 55(38), 48(34), 41(54)$. $95(62), 93(40), 91(32), 81(52), 79(32), 77(24), 67(26), 55(30), 41(50)$. $93(42), 91(40), 81(64), 79(36), 77(28), 67(28), 55(34), 41(48)$. $93(52), 91(58), 81(42), 79(40), 77(34), 67(44), 55(66), 41(78)$. $109(94), 107(82), 106(62), 105(100), 97(36), 95(52), 93(50), 91(60), 81(46), 79(36), 77(30), 67(40), 55(60), 41(82)$. 250 (18), $235(24), 218(14), 191$ (32), $190(28), 175(94), 147$ (18), $135(18), 133(46), 119(100), 107(34), 105(42), 95(18)$, $93(24), 91(50), 83(18), 79(30), 77(34), 55(34), 41(64)$.

Naphthalene- $1(\beta)$-carboxylic acid-1,2,3,4,4a,7,8,8a-octahydro-1,4a( $(\theta), 5,6$-tetramethyl, methyl ester

Corresponds to compound XIa from Anderson and Winans (1991).

Data for compound $21^{*}$, Naphthalene- $1(\beta)$-carboxylic acid-1,2,3,4,4a,7,8,8a-octahydro-1,4a( $\left.\beta\right), 5,6$-tetramethyl, trideutenomethyl ester are given in Anderson and Winans (1991)

$248(16), 216(10), 188(46), 173(100), 159(22), 133(60), 132(52), 119(30), 105(28), 91(36), 79(20), 77(20), 41(42)$. Naphthalene- $1(\beta)$-carboxylic acid- $1,2,3,4,4 a, 7,8,8 \mathrm{a}$-octahydro-1,4a( $\beta), 6$-trimethyl, 5 -methylene methyl ester Corresponds to compound XIIa from Anderson and Winans (1991).

Data for compound $22^{*}$, Naphthalene- $I(\beta)$-carboxylic acid-1,2,3,4,4a,7,8,8a-octahydro- $1,4 a(\beta), 6$-trimethyl, 5-methylene trideuteriomethyl ester, are grven in Anderson and Winans (1991) $107(40), 105(28), 95(100), 93(34), 91(40), 83(32), 81(38), 79(30), 77(26), 67(34), 57(16), 55(54), 41(70)$. $109(54), 107(44), 105(30), 95(100), 93(40), 91(42), 83(38), 81(32), 79(34), 77(26), 67(34), 57(18), 55(52), 41(62)$. $220(28), 205(10), 187(40), 173(24), 159(38), 147(22), 146(25), 145(50), 133(74), 132(10), 119(96), 107(56), 105(70)$, $95(38), 93(54), 91(96), 79(50), 77(52), 67(30), 65(26), 55(58), 53(32), 43(32), 41(90)$. $95(26), 93(36), 91(72), 79(42), 77(44), 67(22), 65(18), 55(46), 53(22), 43(30), 41(66)$.

Mass Spectral data suggest that two or more materials co-elute at this retention time. Based on close similarity of the MS data obtained from both Glessite and Succinite however, it is apparent that the compounds present under this peak are common to both samples. 

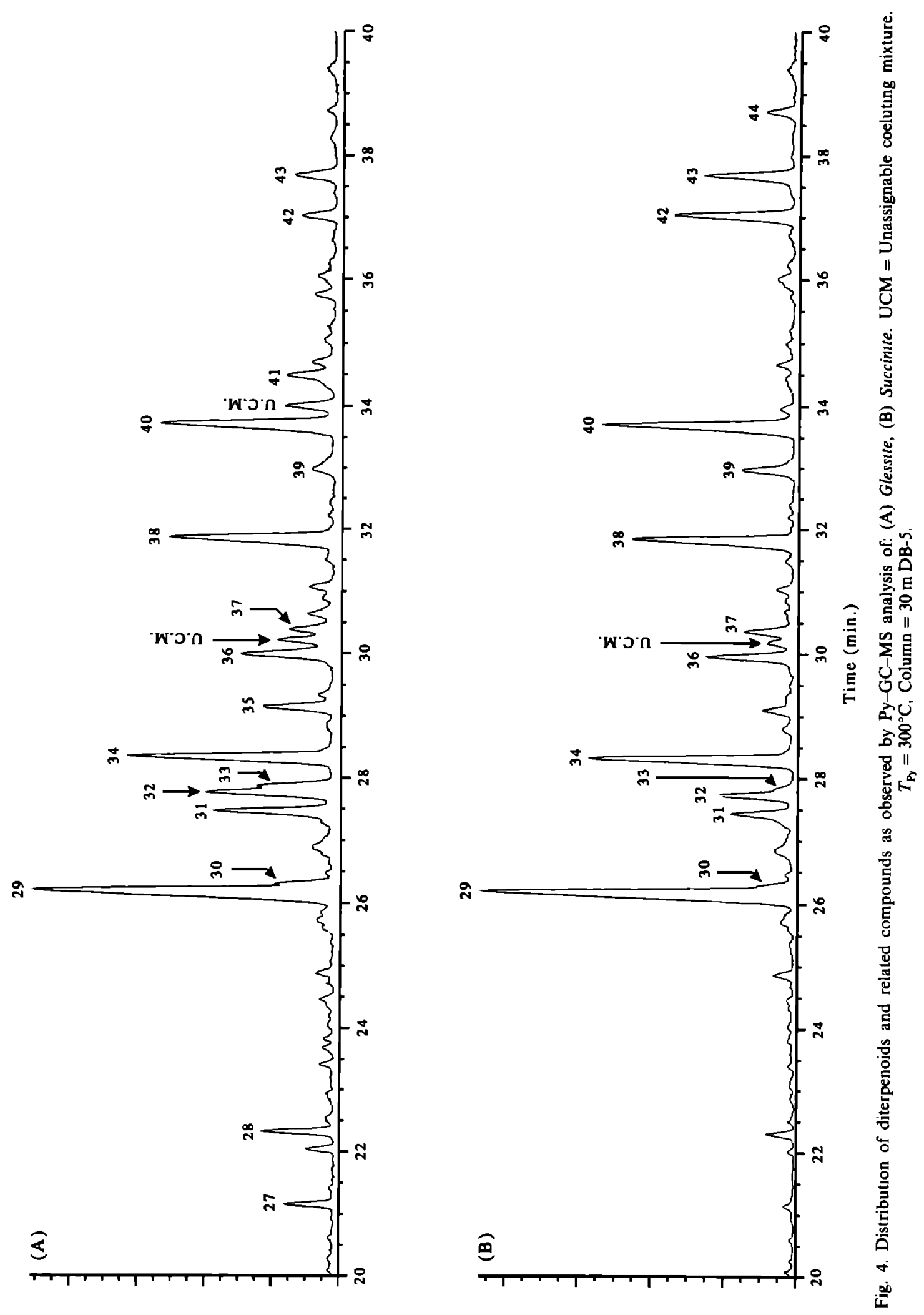
Table 4. MS data from Py-GC-MS analysis of Glessile and Succinite ("intact" diterpenoids)

\begin{tabular}{ll}
\hline Compound & MS data and assignments \\
\hline 27 & $270(30), 256(20), 255(100), 213(14), 199(16), 185(44), 173(84), 159(90), 143(24), 129(32), 128(26), 117(24), 91(16)$, \\
& 69 (58), 55 (26), 43(48), 41 (52). \\
& Dehydroabietin. (Kitadani et al., 1970; Mills et al., 1984/85; McLafferty and Stauffer, 1989).
\end{tabular}

$302(32), 287(48), 257(100), 255(80), 241$ (12), $225(14), 187(40), 175(48), 161(42), 145(54), 133(50), 131(54), 119(52)$, $107(58), 105(74), 95(44), 93(44), 91(80), 81(52), 79(70), 68(50), 55(68), 45(86), 41(80)$ Unassigned.

$316(24), 301(30), 274(10), 257(34), 241(100), 173(20), 159(14), 145(14), 133(18), 121(20), 107(24), 105(30), 93(20)$, $91(38), 81(20), 79(26), 67(20), 55(28), 41(44)$.

Methyl 8,15-isopimaradiene-18-oate (Zinkel ef al., 197I; Mills el al., 1984/85; McLafferty and Stauffer, 1989). Phenanthrene-1-carboxylic acid-1,2,3,4,4a,9,10,10a-octahydro-1,4a,7-trimethyl, methyl ester. (Mills el al., 1984/85).

$316(24), 301(54), 269(10), 257(18), 241(100), 185(18), 159(16), 149(10), 129(10), 121(10), 119(10), 117(10), 107(14)$, $105(26), 91(20), 81(22), 79(14), 59(12), 55(18), 41(22)$.

Methyl 8,15-pimaradiene-18-oate.

$318(18), 303(48), 27 !(12), 259(18), 258(12), 243(100), 229(8), 187(22), 135(14), 133(12), 121(22), 107(18), 105(22)$, $95(14), 93(12), 91(20), 81$ (12), $79(12), 69(12), 55(26), 41(24)$

Methyl 8-pimaren-18-oate (Zinkel et al, 1971; McLafferty and Stauffer, 1989).

300 (16), $285(22), 253(100), 239(8), 211(10), 185(16), 173(58), 159(18), 155(12), 143(10), 141(14), 131(18), 129(16)$, $128(14), 117(12), 83(8), 55(14), 45(26), 43(22), 41(16)$.

Phenanthrene-1-carboxylic acid-1,2,3,4,4a,9,10,10a-octahydro-9-oxo-1,4a,7-tnmethyl, methyl ester (Tentative assignment based on comparison with compound $L$, Table 2).

Methyl sandaracopımarate-MS data corresponds with data for Compound D, Table 2. Structure illustrated in Scheme 1. 302 (72), 289 (38), 257 (32), 255 (40), 241 (36), $229(30), 199(28), 187(34), 185(32), 133(38), 131(38), 121(100), 109(38)$, $107(32), 105(56), 95(46), 93(36), 91(54), 81(38), 79(36), 55(44), 45(46), 43(48), 41(50)$. Unassigned.

Methyl isopimarate-MS data corresponds with data for compound F, Table 2. Structure illustrated in Scheme 1.

Methyl palustrate-MS data corresponds with data for compound E, Table 2. Structure illustrated in Scheme 1. Probably corresponds to Mills et al., 1984/85 Scan \#918.

Methyl dehydroabietate-MS data corresponds with data for compound G, Table 2. Structure illustrated in Scheme I. $350(4), 291(10), 290(18), 271(6), 253(8), 235(6), 221(6), 180(10), 161(12), 121(100), 109(18), 107(18), 105(14)$, $95(14), 93(18), 91(12), 81(30), 79(18), 67(18), 55(24), 45(38)$.

Unassigned Possible analogue of Dimethyl dihydroagathate (\#41 below)

Methyl abietate-MS data corresponds with data for compound H, Table 2. Structure illustrated in Scheme 1 .

$\mathrm{M}^{+}=$? $, 305(58), 221(74), 189(72), 171(34), 161$ (38), 149 (34), $147(32), 135(36), 133(38), 121$ (34), $119(38), 109(44)$, $107(38), 105(40), 98(32), 95(100), 93(38), 91(44), 81(52), 69(40), 67(40), 59(58), 55(64), 45(62), 41(42)$. (Weak Spectrum)

Unassigned

$364(4), 304(26), 273$ (4), $257(6), 235(6), 221(8), 189(6), 181(8), 180(8), 161(16), 121(100), 109(18), 107(16), 105(12)$, $95(16), 93(18), 91(14), 81(20), 79(16), 69(14), 67(18), 59(18), 55(26), 41(28)$

Dimethyl dihydroagathate (McLafferty and Stauffer, 1989).

43

364 (10), 349 (6), 305 (16), 304 (18), 289 (18), 257 (16), 235 (90), 203 (26), 175(100), 161 (14), 159 (16), 149 (14), $147(20)$, $135(20), 133(26), 119(46), 109(22), 107(26), 105(32), 95(28), 93(24), 91(30), 81(30), 79(26), 69(30), 67(18), 59(34)$, $55(46), 43(26), 41(44)$.

Dimethyl dihydro- $\Delta 8$-agathate (Mills et al., 1984/85).

44 $346(12), 305(24), 304(22), 235(56), 175(44), 122(100), 109(60), 107(38), 95(42), 93(28), 81(38), 69(40), 67(30)$, 59 (36), 55 (42), $43(26), 41$ (42). (Weak spectrum). Unassigned. Probably corresponds to Mills et al., 1984/85. Scan \# II50<smiles>CC(C)c1ccc2c(c1)CCC1C(C)(C)CCC[C@@]21C</smiles>

26<smiles>CC[C@]1(C)CCC2=C(CCC3C2CCCC3(C)C)C1</smiles>

31<smiles>C=CC1(C)CCC2=C(CCC3C2CCCC3(C)C)C1(C)OC</smiles>

28

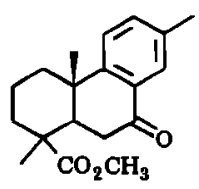

32<smiles>CCOC(=O)C1(C)CCCC2(C)c3ccc(C)cc3CCC12</smiles>

29<smiles>COC(=O)CC1C=C2CCC3C(CCCCC3(C)C)C2CC1</smiles>

41<smiles>C=C[C@]1(C)CCC2=C(CCC3C2(C)CCC[C@]3(C)C(=O)OC)C1</smiles>

30

Scheme 3. Structures of diterpenoids identified in Succinite and Glessite. MS data are given in Table 4. 
resinites and hence the structural characteristics of these samples are closely comparable.

Mass spectral data and, where possible, assignments for compounds $1-26$ are given in Table 3 . The majority of these compounds cannot, at present, be assigned specific structures. However, based on mass spectral and chromatographic data, a small number of significant compounds may be assigned with confidence. In particular, the observation of compounds 15, 21 and 22, which we have reported are characteristic of resinites derived from resins based predominantly on polycommunic acids, and dimethylsuccinate (compound 3), confirm that Glessite is a typical Class Ia resinite.

We have also reported (Anderson et al., 1992) that the ratio of compounds 15,21 and 22 [viz, $15 /(21+22)]$ is related to the maturity of the resinite. Although it is not possible at present to quantify the level of maturity of Class I resinite samples based on the value of this ratio, estimates of relative maturity from this value appear to be reasonable. In this case, the value of this ratio for these two resinites was found to be approximately equal $\quad$ (Glessite $=0.24, \quad$ Succinite $=0.27$ ), which strongly suggests that these samples are of comparable maturity.

It is also apparent from the data illustrated in Fig. 3 that a significant number of "intact" diterpenoids are present in the pyrolysates of these resinites. However, under the conditions used to obtain the data illustrated in Fig. 3, chromatographic resolution of many of these compounds is inadequate for confident identification. Therefore, additional Py-GC-MS analyses in which chromatographic conditıons were modified to obtain better resolution of occluded diterpenoids were undertaken (see experimental section). Data from these analyses are illustrated in Fig. 4. Thirteen of the 18 distinct diterpenoids present in significant abundances in the pyrolysates of these resinites (compounds 27-44), including all of the major components, are common to both samples. Furthermore, as was observed for the non-diterpenoid components of the pyrolysates of these resinites (compounds 1-26) the distributions of these compounds (27-44) are very similar in both samples. In fact, the differences in the diterpenoid distributions observed in these samples are certainly less than differences which are observed between the resin compositions of different populations of the same species (Langenheim, 1990). Mass spectral data and assignments for compounds 27-44 are given in Table 4. Structures not already illustrated in Scheme 2 are illustrated in Scheme 3.

It is apparent from these data (illustrated in Figs 3 and 4, and tabulated in Tables 3 and 4), that the structure and composition of Glessite is that of a typical Class Ia resinite and is very closely comparable to that of the more common European amber, Succinite. There is no evidence in these data which supports the earlier conclusion that this resinite
(Glessite) is based on or related to amyrin derived materials of any kind.

\section{CONCLUSIONS}

It is apparent that our data are inconsistent with the previously assigned structural character of Highgate Copalite and Glessite. Neither of the samples characterized is based on or derived from amyrins or related compounds, nor is either in any way related to elemi resins. Also, neither of these resinites is directly structurally comparable to the other.

The Highgate Copalite sample, herein described, is a non-polymeric mixture of diterpenoid resin acids, (primarily of the abietic, pimaric and iso-pimaric types), $\boldsymbol{n}$-alkanoic acids and $\boldsymbol{n}$-alkanes, and is closely comparable to modern rosin. Hence, it may reasonably be concluded that Highgate Copalite is derived from the resin of an undetermined species of pine. Based on these observations, and also on observations described by Beck and Shennan (1991), it may also be concluded that resinites comparable in character to this Highgate Copalite sample, occur in at least two deposits, and hence represent a discrete form of fossil resin. Therefore, an additional class has been added to the classification system for resinites which we have previously proposed (Anderson et al., 1992).

The results of Py-GC-MS analysis of Glessite, and comparison of these data with the results of similar analyses of Succinite, unequivocally establish that Glessite is a typical Class Ia resinite (Anderson et al., 1992) very closely comparable to Succinite. The extent of similarity of these resinites is such, that the validity of continued distinction between them is, on chemical grounds at least, unjustified.

Beck and Shennan (1991) have suggested on the basis of infrared spectroscopic data, that resinous materials described as Highgate Copalite which are held in a number of collections may be derived from a number of botanical sources. If so, then our observations do not necessarily invalidate the results of $\mathbf{X}$-ray diffraction analysis of these resinites described by Frondel $(1967 \mathrm{a}, \mathrm{b})$, since it is at least conceivable that the samples characterized by Frondel and those described herein may not be directly comparable [Frondel does not cite sample reference numbers in either of her reports $(1967 \mathrm{a}, \mathrm{b})$. Hence it is not possible to deliberately obtain sub-samples of the resinites used in her analyses]. However, given that neither of the resinites described herein is in any way comparable, or related to modern elemi resins, it is clear that the conclusions described by Frondel $(1967 \mathrm{a}, \mathrm{b})$ are at least not generally applicable to these resinites (viz; Highgate Copalite and Glessite). Analyses of Guayaquilite by the authors (Anderson et al, unpublished results), also conflict with the conclusion that this resinite is also a "fossil elemi". It therefore seems reasonable to suggest that the 
conclusions reported by Frondel $(1967 \mathrm{a}, \mathrm{b})$, that these resinites are fossil analogs of elemi resins, be regarded as open to question.

Acknowledgements - The authors wish to take this opportunity to acknowledge Dr Francis Hueber and Dr Peter Dunn of the Smithsonian Institute for generously providing samples of the resinites described herein. Dr John Muntean provided assistance in measurement of some of the CP/MAS ${ }^{13} \mathrm{C}$ NMR spectra described herein. The authors would like to express their gratitude to Professor Curt Beck (Vassar College) for his assistance in obtaining a number of difficult to locate references cited in this report, and for generously providing the authors with a copy of his monograph concerning Ambers in prehistoric Britain. This work was performed under the auspices of the Office of Basic Energy Sciences, Division of Chemical Sciences, U.S. Department of Energy, under contract number W-3I-109-ENG-38.

\section{REFERENCES}

Anderson K. B. and Winans R. E. (1991) The nature and fate of natural resins in the geosphere-I. Evaluation of pyrolysis-gas chromatography-mass spectrometry for the analysis of natural resins and resinites. Anal. Chem 63, 2901-2908.

Anderson K. B., Winans R. E. and Botto R. E (1992) The nature and fate of natural resins in the geosphere-II. Identification, classification and nomenclature of resinites. Org. Geochem. 18, 829-841.

Beck C. W. (1986) Spectroscopic investigations of amber. Appl. Spectrosc. Rev. 22, 57-110.

Beck C. W. and Shennan S. (199I) Amber in Prehtstoric Britain pp. 232. Oxbow Monograph 8. Oxbow Books, Oxford.

Frondel J. W. (1967a) X-ray diffraction study of fossil Elemis. Nature 215, 1360-1361.

Frondel J. W. (1967b) X-ray diffraction study of some fossil and modern resins. Science 155, 1411-1413.

Hafizoğlu H. (1983) Wood extractive of Pinus sylvestris L., Pinus nigra Arn. and Pinus brutia Ten. with special reference to nonpolar components. Holzforschung 37, 321-326.

Herz W. and Mohanraj S. (1980) Structure proof by synthesis of unusual secodehydroabietanes from Tall oul J. Org. Chem. 45, 5417-5419.
Johnston J. F. W. (1839) Ueber einge Mineralharze. J. Prakt. Chem. 17, 107-117.

Kitadani M., Yoshikoshi A., Kıtahara Y., Campello J. D. P., McChesney J. D., Watts D. J. and Wenkert E. (1970) Natural ar-Abietatriene. Chem. Pharm. Bull. 18, 402-405.

Kosmowska-Ceranaowicz B. and Krumbiegel G. R. (1990) Bursztyn Bitterfeldzkı (Saksonski) I inne zywice kopaline $z$ okolic halle (NRD). Przegl. Geol. 38, 394-400.

Lambert J. B. and Frye J. S. (1982) Carbon functionalities in amber. Science 217, 55-57.

Lambert J. B., Beck C. W. and Frye J. S. (1988) Analysis of European amber by carbon-13 nuclear magnetic resonance spectroscopy. Archaeometry 30, 248-263.

Langenheim J. H. (1990) Plant resins. Am. Sci. 78, 16-24.

Mills J. S., White R. and Gough L. J. (1984/85) The chemical composition of Baltic amber. Chem. Geol. 47, 15-39.

McLafferty F. W. and Stauffer D. B. (1989) "The Wiley/ NBS registry of mass spectral data" (computerized data base). Wiley, New York.

Pernet R. (1972) Phytochemistry of the Burseraceae. Lloydia 35, $280-287$.

Soltes E. J. and Zinkel D. F. (1989) Chemistry of rosin. In Naval stores-Production, Chemistry, Utilization (Edited by Zinkel D. F. and Russel J.), pp. 261-330. Pulp Chemicals Assoc.

Takeda H., Schuller W. H. and Lawrence R. V. (1968) Novel ring openings in methyl levopimarate. J. Org. Chem. 33, 3718-3722.

Takeda H., Schuller W. H., Lawrence R. V. and Rosebrook D. (1969) Novel ring openings in levopimaric acid salts. J. Org. Chem. 34, 1459-1460.

Thomson T. (1813) Description of a resinous substance lately dug out of the earth at Highgate. Ann. Philosophy 2, 9-10.

Zinkel D. F. and Foster D. O. (1980) Tall oil precursors in the sapwood of four southern pines. Tappi 63, 137-139.

Zinkel D. F., Rowe J. W., Zank L. C., Gaddie D. W. and Rukel E. R. (1969) Unusual resin acids in Tall oil. J. Am. Oil Chem. Soc. 46, 633-634.

Zinkel D. F., Zank L. C. and Wesolowski M. F. (1971) Diterpene resin acids: a compilation of infrared, mass, nuclear magnetic resonance and ultraviolet spectra and gas chromatographic retention data (of methyl esters). US Dept. of Agriculture, Madison, WI. 